there are but few examples anywhere to be seen, but so late as August and September, I have occasionally taken a $q$, never a $\delta$. In some years two or three, in others none. I have always confined these females for eggs, but have failed to get any. On dissection a few nearly matured eggs would be found imbedded in fat, and I had some time ago concluded that these eggs probably were not impregnated, as I had seen no late males.

But this last September, I received from Mr. Lewis Ullrich, of Tiffin, Ohio, several hibernating cases of Ursula and a chrysalis. Mr. Ullrich wrote me that on 26th Aug., he obtained from a female tied in a bag over a branch of apple tree I 3 eggs, from which he got i I larvæ. Of these, 6 went into cases when half grown, I died when $3 / 4$ grown, and 4 went to chrysalis. Two of the chrysalids produced fernales, and these Mr. Ullrich sent me. I dissected one of them, and could discover no signs of eggs. Certainly there were no eggs formed. The other female I sent to Mr. C. S. Minot, who has not reported on its condition.

This then accounts for the late examples of Ursula seen on the wing. Part of a brood may go into winter cases, while some go on to chrysalis and imago. But the existence of the species does not depend on these late, or September butterflies. Far from it! Disippus does not behave like Ursula in this respect, as observations show, and there is no evidence that Arthemis does. And yet, if any Arthemis, in any locality, are to be found flying in September, their presence may be accounted for by supposing that here and there a larva has passed the hibernating stage and gone on to butterfly, without there being a "second brood."

\title{
NEW SPECIES OF TINEID $Æ$.
}

BY MARY E. MURTFELDT, KIRKWOOD, ST. LOUIS, MO.

Gelechia Chambersella. - In some notes on the larvæ of certain Tineids, published in Vol. vi., No. I 2 of the Canadian Entomologist, I referred to an interesting species found on Ambrosia artemesiafolia, which I proposed soon to describe under the above name. The description was indefinitely delayed by a vexatious accident by which I lost all my perfect specimens. For several succeeding years I searched in vain for 
the larvæ, and as the moth is not attracted by lamp-light, I began to despair of ever replacing the lost specimens. During the past summer, however, I was successful in taking several of the larvae, from which I obtained three imagines, and am thereby enabled to prepare the history of the insect for publication

(My acknowledgments are here due to Mr. V. T. Chambers for the generic determination of this and the following species, and for much other assistance in my studies of this group of Micros. I am also indebted to Prof. O. S. Westcott, of Chicago, for valuable suggestions as to the selection and etymology of the names )

Imago: Alar expanse 0.35 inch, length 0.20 inch. General color of head and body cream-white, shading to buff on abdomen. Head variegated with fuscous scales; vertex roughened but scarcely tufted; palpi slightly exceeding the vertex, second joint brush-like, terminal joint smooth and slender; antennae rather short, dingy white, obscurely annulated with fuscous.

Ground color of primaries dingy white, thickly overlaid with fuscous scales arranged in eight or nine obscure vittae, most pronounced on apical third, with a more or less distinct fulvous spot on the outer edge of disk ; outer margin dark; ciliae checkered white and fuscous. Secondaries silky, pale cinereous. Legs cream white, tibiae of hinder pair clothed with long, somewhat iridescent hairs; tarsi with fuscous annulations.

The larva inhabits a fusiform case formed by webbing together the slender divisions of the leaf, from which it eats the parenchyma of the upper surface, the latter being folded inside. Its average length is 0.35 inch; slender, cylindrical, sub-moniliform. Head small, polished, dark brown. The arrangement of colors on the body is striking and characteristic. First segment narrow, dark brown with small, transversely oblong, yellowisb shield. Second and third and sixth and seventh segments velvety black or very dark brown, with conspicuous milk-white fold on posterior edge. Fourth and fifth segments uniform velvety black. Remaining segments similar with the addition of an oblique lateral white band on each anterior edge. Hairs fine, short and black. The larva makes several cases in the course of growth and changes to pupa within the last, enclosed in slight cocoon. The imago appears in July and early in September.

Gelechia Formosella.-This species bears considerable resemblance to G. maculimarginella Cham., but is nearly one-half larger, the alar 
expanse being from 0.70 to 0.75 inch. The colors are also much deeper, more contrasted and somewhat differently disposed.

Face golden buff, vertex dark silvery, second joint of palpi pale ochreous dusted with brown, terminal joint very acute dark brown, antennae pale purple-brown.

Thorax and primaries dark slate gray with purplish reflections and variegated with small irregular ochreous and dark purple dots. There is a conspicuous purple spot on the costa at the outer edge of the basal third, and obliquely forward and below this a large irregular purple discal spot with minute ochreous dots on its inner margin. The outer one-third is entirely dark brown with purplish reflections brightened by a distinct costal streak of cream white and a similar opposite dorsal streak. Ciliae pale brown. Secondaries cinereous, shading to pale brown on costal edge. Abdomen same color. Legs pale ochreous variegated with brown.

The larva feeds on the Laurel Oak in May, rolling the leaves. It is of a pearl gray color ornamented with eight fine longitudinal purple or dull red lines. Head polished black. First segment narrow and constricted, corneous, black; second segment velvety chocolate brown edged anteriorly and posteriorly with white, third segment also edged anteriorly with white. Venter and prolegs translucent greenish white. Thoracic legs black. Pupa enclosed in slight cocoon within folded leaf. Imago appears about the middle of June. Rather rare.

Gelechia cinerelia.--The general color of this species is ochreous cinereous in all its parts. Head and thorax paler than the wings, inclining to cream color. Palpi simple, not exceeding the vertex. Primaries variegated with a few longitudinal fuscous streaks and a marginal row of minute black dots at the base of the ciliae. Alar expanse 0.45 to $0.5^{\circ}$ inch. Length 0.20 inch.

The larva may be found during June and July mining and crumpling the edges of the leaves of the Horse Nettle (Solanum carolinense), causing them to turn brown as though seared by fire. Inside the puffy mine the larva forms and inhabits a tough silken gallery to which the frass is attached externally and upon which the edge of the leaf is gathered. The larva is cylindrical, rather thick and about one-third of an inch in length at maturity. It is of a translucent green color, the thoracic segments acquiring a blue tint after the last moult. Piliferous spots glassy, giving rise to short light hairs. Head and shield bright brown. When ready to transform it deserts its mine and forms a tough, oval cocoon on the sur- 
face of the earth. Imago appears in from twelve to fifteen days, and there are at least two successive broods.

Gelechia Beneficenteit.A.-Cround color of head, body and primaries pale buff or cream with ochreous shadings and a sparse dusting of blackish scales. Palpi exceeding the vertex, second joint thickened but smooth, terminal joint with two broad dusky bands. Primaries ornamented with numerous, rather indefinite maculae, of a blackish or dark steel gray color, producing on the light ground a somewhat checkered appearance. The dark color predominates toward the apex of the wing, and the outer border and ciliae are of the same dark shade. Secondaries broad, silky, cinereous with slight iridescence, ciliae a shade or two paler.

Legs cream color, dusted with blackish scales, tibiae of hinder pair densely tufted. Alar expanse from 0.70 to 0.75 inch.

The first brood of larvae may be found early in May folding the terminal leaves of Solanum carolinense into round, hollow balls, each of which forms the habitation of a single larva which feeds on the incipient flower buds and the infolded edges of the tender leaves. Length of larva from $0.5 \circ$ to $0.60 \mathrm{inch}$, fusiform, greatest diameter 0.10 . Color dull yellowish green with dark-glaucous vesicular stripe. Head horizontal, cordate, about one-half the width of middle segments, black when young, later assuming an olive brown hue. Cervical shield corneous, rectangular, covering about two-thirds of the first segment, of an olive brown color. Piliferous plates minute, pale brown, each giving rise to a short light hair.

Pupa elongate, dark brown, without marked characteristics, suspended in the midst of a mass of fine, webby matter with which the mature larva fills its leafy domicile, an opening being also prepared through which the future moth can make its exit. Imago issues within two weeks. A second brood of larvæ soon follows.

The specific name for this insect was selected with reference to its services in the larva state, in preventing, to a considerable extent, the blossoming and fruiting of one of our most pernicious weeds.

LITHOCOLLETIS GREGARIELLA - Ground color rich purple-brown with golden reflections. Two conspicuous golden-white fascia cross the basal and discal portions of the primaries. The apical one-third is ornamented with two white costal streaks and one dorsal streak opposite the inner costal one. Ciliæ dingy white. Secondaries very narrow, steel gray. Head purplish, iridescent, antennae dark purple conspicuously tipped with 
white. Expanse 0.I5 to 0.1 8 inch. This species is closely allied to $L$. desmodiella Clem., but Mr. Chambers notes the points of difference as follows: "There is a shade of difference in the ground color, face not white as in desmodiella, though with a silvery or opalescent lustre; the dark margins of the fasciae and streaks are less distinct; it has no distinct dorsal mark opposite the costal one before the ciliae, and the apical part of the wing is not darker than the remainder; it is also a little larger than desmodiella."

The larva belongs to the cylindrical group, is of a whitish green color, and attains a length of about 0.14 inch. It mines the leaves of the Wild Bean (Phaseolus pauciflorus). Its chief peculiarity is found in its gregarious habit, from five to fifteen imagines sometimes emerging from the large tentiform mine. The parent moth places her eggs here and there upon the under surface of the leaf, upon which the work of the young miners is soon apparent in the form of numerous minute blisters, which as they are enlarged, become confluent, and the congregated larvae soon devour every particle of the green tissue of the leaf, which puffs out into a cylinder. When mature the larvae construct in common a loose hammock-like web, within which they change to slender honey-yellow pupae. The imagines of the midsummer brood appear in twelve or fourteen days from the change to pupae. The second brood hibernates in the pupa state.

\section{MR. SCUDDER'S "BUTTERFLIES." \\ BY S. H. PEABODY, CHAMPAIGN, ILL.}

This long promised and lately issued book wants little that the skill of artizan or the genius of artist can furnish. The Entomological brotherhood-those lovers of the net and flask, who, gentler than the historic angler, impale not even a worm until it has become insensible to painthey and the general public will find some store of delightful reading within its pages. Whether, as has been more than hinted, there are notable omissions of valuable matter observed and reported, and bearing with force upon topics treated therein, or not, there is enough of what $\mathrm{Mr}$. Scudder has himself seen, to make the volume a valuable addition to the literature of Psyche. 